\title{
NOTES
}

\section{A SHEAF OF UNCOLLECTED NINETEENTH-CENTURY WHITMAN NOTICES AND REVIEWS}

I list below, and quote relevant material from, eight items in nineteenth-century magazines and newspapers that have been hitherto lost to Whitman scholarship. Among these items are a pair of passing notices in the New York Tribune to early Whitman stories; a review in Ireland of the second edition of Leaves of Grass; and several reviews of Drum-Taps and Specimen Days. These reviews supplement those collected in Kenneth M. Price's Walt Whitman: The Contemporary Reviews (Cambridge: Cambridge University Press, 1996).

1. New York Tribune, December 4, 1841, 2:4.

"Walter Whitman" contributes "Bervance," "a powerful and exciting story," to the Democratic Review for December 1841.

2. New York Tribune, May 7, 1842, 1:1.

The Democratic Review for May 1842 contains “'The Child-Ghost,' a tale by Walter Whitman. ..."

3. "Notices of Books," review of Leaves of Grass, Dublin Review, 41 (September 1856), 267-268.

"We have glanced through this book with disgust and astonishment;-astonishment that anyone can be found who would dare to print such a farrago of rubbish,-lucubrations more like the ravings of a drunkard, or one half crazy, than anything which a man in his senses could think it fit to offer to the consideration of his fellow men. Where these bald, confused, disjointed, caricatures of blank verse have any meaning, it is generally indecent; several times execrably profane. We should not have bestowed one line of notice upon such an insult to common sense and common propriety, as this book, but that, to our unspeakable surprise, we find bound up with it extracts from various American papers highly laudatory of this marvellous production: and we think it right to call the attention of our American readers to the fact, that any (even of the meanest) of their literary critics, should be mistaken enough to lend a sanction to such trash as this."

4. "Book Table," review of Drum-Taps, Independent, December 7, 1865, 2.

"The reader who is acquainted with the noble service that Walt Whitman has rendered to our wounded soldiers will feel inclined to judge favorably of his poetical efforts. He will also be impressed with the fact that the author is possessed of much poetic feeling; but yet will scarcely be convinced that the disjointed prose of 'Drum-taps' is entitled to be considered as poetry. There is a sense in which we speak of the poetry of the clouds-formless, voiceless as 
they are. In a somewhat similar sense 'Drum-taps' may be called poetry. The lines therein contained, while they are as ragged and broken as the stormcloud, and as destitute - many of them - of any intelligible utterance, yet leave with the reader a vague sense of poetic exaltation. Undoubtedly, the author has capabilities. There are passages in the lines entitled 'Captain, My Captain,' and in the war-lyric commencing 'Beat, beat, drums,' that give abundant evidence that Walt Whitman could write true poetry if he would only consent to write either rhyme or reason. His absurd theories of composition have hitherto prevented him from doing either, except at the rarest intervals."

\section{Review of Drum-Taps, San Francisco Bulletin, December 18, 1865, 5:5.}

"Walt Whitman is the Poet of the Roughs. His style is as rowdyish as his habits. Some years ago he published a volume of trash entitled Leaves of Grass, in which he modestly characterized himself as 'Kosmos.' It was worse than stupid, it was beastly. This last effort lacks the obscenity of its predecessor, but it is equally destitute of merit. We cannot imagine any punishment more dreadful than that of being compelled to read it through."

\section{6. "Leaves of Grass," Boston Sunday Globe, August 6, 1882, 3:6.}

"We believe that literary folk will be glad that Walt Whitman has found his publisher, and that the interests of American literature, which owes a good deal to Walt Whitman, will be regarded by the publication of all of his poems. Not a single one should be omitted, as all are needed to indicate the measure of his genius and to preserve the harmony between his purpose and his accomplishment. We believe that this harmony expresses a deep religious feeling. There is no immorality in Walt Whitman, or in his poetry, to the reader who has poetic instinct and poetic insight with that imagination and studious penetration which the correct reading of true poetry always implies. Poetry does not require metre, rhythm, or any particular form for its expression; poetry has an unlimited range of all subjects, and the right to treat them in its own way; poetry always has an ulterior and worthly purpose, to which its expression is only a mode of approach; poetry demands of its readers understanding, imagination and fancy. This book is an American classic."

7. "Walt Whitman's Prose," review of Specimen Days, New York Sun, November 5, 1882, 2:4.

"The author of 'Leaves of Grass' has published a volume made up of odds and ends in prose and entitled 'Specimen Days.' It is a heterogeneous collection of autobiographical notes, extracts from diaries, early writings, and recent contributions to periodicals. It contains a good deal that is interesting, with a good deal that need not have been revived. Mr. Whitman himself does not seem to be quite sure why he has pursued so comprehensive a scheme of preservation. The explanation could perhaps be found in a certain naïve vanity which extends its protection to every scrap of paper bearing the memorandum of an idea or the record of a fact.

We are obliged to confess that Walt Whitman's prose is best when it is least characteristic. When he writes simply, forgetting himself and his responsibilities as the apostle of a new school, he is often very interesting, as notably in his accounts of hospital experience during the war. But he generally remembers 
himself pretty soon, and with the return to self-consciousness comes a certain straining after effect that is not always pleasant. Many passages have little but continuous typographical arrangement to distinguish them from his poetry. Here, for example, is a paragraph which we have divided into verses with other alteration. He has been describing a scene of massacre:

Multiply the above by scores, aye hundreds;

Verify it in all the forms that different circumstances, individuals, places, could afford; Light it with every lurid passion, the wolf's, the lion's lapping thirst for blood, The passionate, boiling volcanoes of human revenge for comrades, brothers slain; With the light of burning farms, and heaps of smutting, smouldering black embers, And in the human heart everywhere black, worse embersAnd you have an inkling of this war.

Mr. Whitman rescues from oblivion the names of some of the chieftains who flourished in the Homeric age of Broadway stage driving. In the days when the Red Birds and Yellow Birds, the Knickerbocker and Fourth avenue and the old Broadway lines were still crowding the thoroughfare now occupied by the Fifth and Madison avenue and Twenty-third street stages only, he used to study and admire the wonderful qualities of Broadway Jack, Dressmaker, Balky Bill, George Storms, Old Elephant (and afterward his brother, Young Elephant), Tippy, Pop Rice, Big Frank, Yellow Joe, Pete Callahan, Patsy Dee, and others of equal professional rank. He used to ride on top of the stages day and night beside these quick-eyed heroes, and astonish them by declaiming passages from Shakespeare above the rest of Broadway. 'I suppose the critics will laugh heartily,' he says, with unconscious humor, 'but the influence of those Broadway omnibus jaunts and drivers and declamations and escapades undoubtedly entered into the gestation of 'Leaves of Grass."'

8. "New Books," review of Specimen Days, Philadelphia Press, December 8, 1882, 7:3.

"Mr. Whitman's 'Specimen Days and Collect' is a book to be picked up at an odd moment and read in instalments, like the letters of a friend. It is as full of individuality as an egg is of albumen. It gives one insight into the mind of the poet. The 'Specimen Days' are of course extracts from diary memoranda. They are as odd as a Chinese picture; different from anything else in the literary line ever published. It is curious to wander back through the years with the 'Good Grey Poet' and read his thoughts, see with his eyes and be affected through his nerves and sensibilities. It is no small privilege. They are gathered together at hap-hazard, and that only adds to their nameless charm; nameless because so unexpected and that nothing quite meets their nomenclature.

The latter half of the volume is an olla podrida of notes, essays, lectures and memoranda with one or two poems. Here at last is a book by Walt Whitman, in whose pages no mawkish morality and squinting prudery can find a line to erase or change. It is as pure as the mountain wind and as free. It is not an easy book to characterize, but it is a book which every lover of our literature will prize not only as a curiosity but as full of things worth remembering." 